\title{
Career Development Model and Awarding System for Athletes and Former Athletes in Indonesia
}

\author{
Nuryadi Nuryadi*, Yusuf Hidayat, Dian Budiana, Jajat Darajat KN \\ Physical Education Departemen \\ Univeristas Pendidikan Indoensia \\ Bandung, Indonesia \\ *nuryadi_fpok@upi.edu
}

\begin{abstract}
Competitive sports are becoming popular nowadays. The increasing growth of participants in sporting events proves that many individuals are interested to contribute in competitive sports. However, this development is not followed by the awareness that individuals will experience a post-career stage. This research was aimed at exploring local and central government's supports and policies in handling the career of athletes and former athletes in Indonesia. Asides from that, the purpose of this study was to analyze how the government handled the awarding system for athletes and former athletes in Indonesia as well as their transition period. The result of this study shows that there is no model for the retirement of athletes from several regional sports organizations in Indonesia. Therefore, this study suggests that government needs to develop a career development model for Indonesian athletes as a way to help them to face their career transition.
\end{abstract}

Keywords: career development, coaching model, former athletes

\section{INTRODUCTION}

Competitive sport is an activity where an individual shows a tendency to achieve specific goals in sport activities [1]. Nowadays, competitive sports and achievements continue to be demanded by various communities and the number of it is always increased year by year. This is illustrated by the increasing number of participants from various regions who participate in sport activities or championships organized by the branch of sport association or government.



Fig. 1. The growth of the parcipants of PON.
The increasing number of participants in competitive sport can give many benefits. However, some athletes often forget that their competitive career is only a halfway in their lives and most of them do not consider their post-athlete career. According to Ogilvie and Taylor, the competitive sports career of an individual can be ruined by some factors such as age, unselected, injury, and free choice [2].

The retirement factor for athletes is different in each country. For example, European and North American Olympic athletes chose to stop their careers voluntarily [3]. The research that is conducted for the retired Yugoslavia and Czechoslovak athletes justifies that the reason why they stopped working is because of injury, age and their non-selection status [4]. Furthermore, the research on Canadian athletes shows that they stop their career because they feel bored with their lifestyle [5].

Post-athlete career is a phenomenon that attracts public attention. Not only in terms of their success in living their retirement, but also in terms of their failure. Athletes who have planned to retire from the beginning will not waste their energy. They can mobilize and use their resources more effectively than athletes who do not plan their retirement [6].

Post-athlete career planning includes psychological preparation that is done before their competitive career. It also has a clear goal to make the athletes comfortable to go out from their comfort zone [7].

Australia has become a country that has successfully supported elite and amateur athletes to prepare their postathlete careers. Some of these assistance programs are the Athlete Career Education (ACE) Program, the Life Skills for Elite Athletes Program (SportsLEAP) and the Olympic Job Opportunities Program (OJOP) [8]. In addition, Scotland provides a job search and skills development program for athletes who are very useful for former athletes in the country [9].

In relation to the need of knowing the post-athlete career preparation in each region, a further research on this issue should be conducted in order to be used as a reference for further research to determine appropriate model in fostering athlete retirement. 
Sinclair and Orlick reported that one-third of amateur and

\section{METHOD}

The methodology that was used in this study was a survey method. The survey was conducted on the Department of Sports and Youth and former athletes by using snowball sampling. The instrument used in this study was a questionnaire about the development of Indonesian athlete career models that are framed by Stambulova Career Development theory [10]. After the data is obtained, the analysis used in this study is the percentage analysis technique to see the level of retirement preparation program in each region.

\section{RESULTS AND DISCUSSION}

In some provinces, the support and policies of the local and central government in dealing with athletes and former athletes have not been fully in line with expectations. This is illustrated by the initial analysis which refers to the Stambulova Career Development theory which consists of (1) the beginning and then the specifications of the sport branches, (2) intensive training in a specific sport, (3) the transition from junior to senior to achieve top performance, (4) transition from amateur to professional status, (5) from top achievement to end, (6) retirement [10].



Fig. 2. Implementation career development.

The result of the analysis shows that there is no model for athlete retirement development program. This becomes a significant finding that needs to be considered, because basically retirement is a transition period for athletes.

This result supports several previous researches which relate to the career transition period that has been widely carried out by global researchers such as Atchley with his or her continuity theory which argues that retirement is perceived as a process in the continuity of the role of the past [11]. Rosenberg argued that retiring from a sports career can be metaphorically considered as social death, which is characterized by isolation and rejection from groups where the athletes participate [12]. Werthner and Orlick found that $78 \%$ of Canada's elite athletes experience emotional difficulties after leaving the sport and $32 \%$ of them characterize the transition period as an "extremely difficulty" period [13]. Elite athletes in their career will face 6 transitions, and the most critical period is the end of achievement (before retirement) and postathlete [10]. In addition, another group of researchers found that career transitions can cause mental health issue that occurs in various forms. professional athletes experience serious problems due to the loss of the social aspects of their sport. This pressure caused by job losses and financial problems. In addition, the study shows that $11 \%$ of them were dissatisfied with their lives since the retirement and $15 \%$ of them felt they could not handle career transition issues well [5].

Therefore, this finding becomes one of the recommendations for further research related to the development of career pattern coaching program to prepare the athletes in their transition period. The role of athletes when they were in their top achievement is one of the important things for the international achievement of competitive sport activities in our country. Therefore, the role of the government in preparing athletes at retirement should be structured by investing in various forms of investment such as schools, vocational training, health services, relocation, and the source of information about income. Asides from that, the education investments in developing human capital because "Education and training are the most important investments in human capital" [14]

\section{REFERENCES}

[1] R.S. Vealey, "Conceptualization of sport-confidence and competitive orientation: Preliminary investigation and instrument development," Journal of Sport and Exercise Psychology, vol. 8(3), pp. 221-246, 1986.

[2] B. Ogilvie and J. Taylor, Career termination issues among elite athletes. In R. N. Singer, M. Murphy, \& L. K. Tennant (Eds.), Handbook of research on sport psychology, New York: Macmillan, 1993, pp. 761775.

[3] P. Wylleman, P. De Knop, H. Menkehorst, M. Theeboom, and J. Annerel, Career termination and social integration among elite athletes, 1993.

[4] B. Svoboda and M. Vanek, "Retirement from high level competition," In Proceedings of the 5th world congress of sport psychology, pp. 166-175, 1982.

[5] D.A. Sinclair and T. Orlick, "Positive transitions from high-performance sport," The sport psychologist, vol. 7(2), pp. 138-150, 1993.

[6] D. Alfermann, N. Stambulova, and A. Zemaityte, "Reactions to sport career termination: a cross-national comparison of German, Lithuanian, and Russian athletes," Psychology of sport and exercise, vol. 5(1), pp. 61-75, 2004.

[7] S. Park, D. Lavallee, and D. Tod, "Athletes' career transition out of sport: a systematic review," International Review of Sport and Exercise Psychology, vol. 6(1), pp. 22-53, 2013.

[8] Australian Institute of Sport, Athlete career and education program: A balanced approach to sporting excellence. Canberra: Australian Institute of Sport, 1995.

[9] O. Gilmore, Leaving competitive sport: Scottish female athletes' experiences of sport career transitions, 2008

[10] N. Stambulova, D. Alfermann, T. Statler, and J. CôTé, "ISSP position stand: Career development and transitions of athletes," Internationa journal of sport and exercise psychology, vol. 7(4), pp. 395-412, 2009.

[11] R.C. Atchley, "A continuity theory of normal aging," The gerontologist, vol. 29(2), pp. 183-190, 1989.

[12] E. Rosenberg, "Athletic retirement as social death: Concepts and perspectives,". Third Annual Meeting of North American Society for the Sociology of Sport, Toronto, Canada, 1982.

[13] P. Werthner and T Orlick, "Retirement experiences of successful Olympic athletes, "International journal of sport psychology, 1986.

[14] Becker, G. S. (1995). Human capital and poverty alleviation. World Bank, Human Resources Development and Operations Policy. and training of athletes should be the most important 